\title{
Lack of maintenance is a major challenge for stream restoration projects
}

\author{
Harriet Elizabeth Moore ${ }^{1}$ and Ian D. Rutherfurd ${ }^{2}$ \\ 1. School of Geography, The University of Melbourne, 221 Bouverie Street Carlton VIC, 3053. hemoore@unimelb.edu.au \\ 2. School of Geography, The University of Melbourne, 221 Bouverie Street Carlton VIC, 3053. idruth@unimelb.edu.au
}

Abstract

Environmental infrastructure and practices designed to restore and protect aquatic systems are now mainstream. Yet, many of these projects are failing to produce the biophysical outcomes that they are designed for because of poor maintenance. The success of restoration projects is just as much a consequence of how they are maintained, as it is how the project was initially designed and implemented. Successful maintenance relies on understanding the ecological and biological recovery trajectories of aquatic systems. Some interventions will require ongoing maintenance indefinitely, whilst others will reach a self-sustaining point where maintenance is no longer required. Different management arrangements are required to ensure the maintenance of different types of project. Those projects that involve high costs should be managed using more robust arrangements, such as legal regulation, compared to those projects that involve lower costs. This paper describes the maintenance required for common river restoration projects and outlines a classification of projects based on maintenance and recovery trajectories. It then considers the types of management arrangements required to ensure maintenance. Finally, these points are illustrated with three case-studies of typical restoration actions (riparian stock exclusion, fish passage, and restoring large wood

loads). Projects that require ongoing maintenance, particularly those that involve high costs, such as environmental flows, require strong management arrangements to ensure successful outcomes.

Voluntary instruments are more appropriate for self-sustaining interventions. Regardless of the chosen management arrangements, monitoring and independent assessment are essential for successful maintenance.

\section{Keywords}

River restoration, maintenance, environmental management, recovery, trajectory.

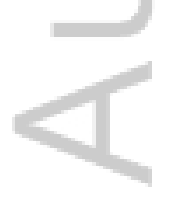

This is the author manuscript accepted for publication and has undergone full peer review but has not been through the copyediting, typesetting, pagination and proofreading process, which may lead to differences between this version and the Version of Record. Please cite this article as doi: $10.1002 /$ rra.3188

This article is protected by copyright. All rights reserved. 


\section{Introduction}

Over the last thirty years, the focus of river and stream management has shifted from utilitarian benefits such as flood prevention (Tompkins \& Kondolf, 2007), towards restoring natural values to waterways, and protecting ecosystem services (Bernhardt et al,. 2007). This period has been an experiment in designing and establishing solutions to degradation (Kondolf et al., 2007). Bernhardt et al. (2005) found that the most common river restoration projects in North America are: 1) riverbank stabilization and stock exclusion; 2) instream activities, such as habitat creation and stocking of native species; 3) morphological activities (such as natural channel design); and 4) reconnection activities, such as environmental flows, fish-ladders, and dam removal.

The emphasis in the literature has been on initiating river restoration projects, including encouraging communities to adopt restoration practices, establishing legislation to restore public waterways, and improving the quality and assessment of new projects. There have also been many calls to better monitor and evaluate the performance of works and projects (Palmer et al., 2007; Brooks \& Lake, 2007), and develop guidelines for restoration (Beechie et al., 2010). Studies of restoration interventions now demonstrate the challenges with the design (Roscoe \& Hinch, 2010), construction (Heede, 1977), monitoring (Bernhardt et al., 2007; Kondolf et al., 2007), evaluation (Morandi et al., 2014; Kemp, 2016), and initial implementation. Many restoration projects have failed because they were poorly designed (Nagle, 2007); because they were treating the wrong problem; or because they were not tackling the fundamental constraints of the catchment (Lorenz \& Feld, 2013; Palmer et al., 2010). Continuing to maintain structures, works, or practices that are not succeeding is unwise; but failing to maintain works or practices that are succeeding is equally wasteful.

In the early days of river restoration it was appropriate that the focus was on ecological goals, honing the design of interventions, and establishing the political consensus to support these activities (Ormerod, 2004). But as the industry has progressed, a key issue now is how to maintain interventions over the long-term in order for infrastructure and practices to persist. Examples of well-designed projects that fail due to poor maintenance include mitigation wetlands (Hallwood, 2007), and projects to return large wood to streams (Shields et al., 2006). This paper outlines the problem of 'river restoration persistence'. This is defined as the failure to maintain activities to achieve the desired environmental outcomes, including the upkeep of infrastructure, and continuing practices over the length of time, and with the appropriate regularity, to achieve goals. This problem is fundamentally linked to how projects are managed. River restoration maintenance can involve the upkeep and replacement of physical infrastructure, continuing site management practices, as well as the effective ongoing communication of project goals to community groups and individuals involved. Overall, we argue that how projects are managed and maintained in the long-term, is as important to their success, as how they are physically designed and implemented.

To improve the success of future restoration projects, we must understand why maintenance is neglected and how lack of maintenance affects different types of interventions. This necessarily involves looking beyond the hydro-geomorphological, and ecological spheres of research, and engaging with the social sciences (Palmer et al., 2014). Restoration can involve regulating private 
businesses, as well as encouraging landholders to voluntarily change the way that they manage resources in river basins. In addition to legal regulations, mechanisms such as market-based instruments, devolved grants, and voluntary agreements are commonly used to encourage landholders to participate in restoration projects (Danne, 2003). To be effective, these delivery mechanisms must be suited to the length of time that infrastructure and practices must be maintained to produce outcomes.

In this paper we:

- Describe the most common types of river restoration projects, and the activities that they involve, both initially and for maintenance;

- Outline a classification of interventions in terms of different biophysical trajectories of recovery, and demonstrate that the length of time required for recovery should inform decisions about how interventions are managed;

- Discuss the implications of maintenance for making decisions about the institutional arrangements used to manage projects over the long-term, suggesting that the success of restoration is related to choosing policies and mechanisms that suit the time required for asset recovery; and

- Illustrate the issues of maintenance using three case-studies of restoration projects in Australia.

The examples and case-studies referred to throughout this paper are primarily from river restoration projects in south eastern Australia. This is because the authors had to draw on detailed information from managers and government agencies that were available to them. However, stream restoration projects and practices are not substantially different in SE Australia from Europe and North America (Brooks and Lake, 2007; Fryirs et al. 2013). Interventions such as fishways, environmental flows, fencing the riverbank to exclude stock, and returning woody debris to channels, are practiced in many western countries. We are confident that the key principles of the paper, the classification of river restoration interventions, and the implications for management, can be applied globally.

\section{Types of river restoration projects}

Bernhardt et al. (2005) identify 13 categories of river restoration projects based on the stated goals of projects listed in the National River Restoration Science Synthesis database. From these categories we have identified four project types: riparian, morphological, reconnection, and instream. Restoration activities can also be classified as 'active' where it involves intervention (such as the establishment of infrastructure, or the performance of a practice); or 'passive' where it refers to 'stopping' existing degrading practices and allowing systems to recover naturally without further intervention (e.g. Wheaton et al., 2008; Giller, 2005; Rowanza et al,. 2013). The projects discussed by Bernhardt et al. (2005) are all active, as opposed to passive, restoration activities.

A foundation of environmental restoration is that the improvement achieved through intervention should persist (Simenstad et al., 2006). Interventions fail to produce ecological outcomes when projects are not maintained over an appropriate timeframe for degraded environmental assets to recover. This implies that there is a clear goal or endpoint defined for a restoration project. Many critiques of restoration projects have identified that the specific goal of projects is poorly defined (Brooks \& Lake, 2007). Palmer et al. (2007) state that one of the requirements of a good restoration project is: 'a dynamic ecological endpoint', although they expressly state that they 'use the term 
ecological in a very general sense to include biological, hydrological and geomorphic aspects of natural systems" (p.3). Endpoints, or exit points, can involve targets for specific species, but they can also involve intermediate physical targets, such as reduced erosion rates.

Some interventions require regular maintenance indefinitely to achieve restoration outcomes. These we term 'ongoing' interventions. Others are likely to require less maintenance over time, and, if managed well, can reach a point where recovery is self-perpetuating. These we term 'self-sustaining' interventions. We have identified three features of river restoration interventions that determine whether they are likely to be self-sustaining or ongoing: the type of maintenance required for the intervention to produce ecological outcomes, the resilience of an intervention (such as infrastructure) to disturbance (such as flooding), and whether the intervention addresses an underlying cause of degradation or a symptom of that degradation.

\section{Types of Maintenance}

There are three types of maintenance that may be involved in ensuring a restoration intervention achieves target outcomes:

1. Routine operational maintenance to ensure function (weeding riverbank revegetation sites, delivery of environmental flows, removal of accumulated debris on fishways). Routine maintenance should be conducted following a pre-determined maintenance schedule.

2. Disturbance related maintenance (removing racked debris from riverbank fencing after flooding (Department of Environment, Land, Water and Planning, 2015), conducting sediment extraction from high-value river reaches after flooding). This maintenance requires project monitoring after disturbance events.

3. Lifecycle maintenance including the eventual replacement of an intervention, usually a structure (partial or full replacement of a fishway, refurbishment of a flow-regulator). This maintenance requires monitoring to evaluate the condition of infrastructure, and timely planning for refurbishment.

Ongoing interventions are likely to require all three types of maintenance, indefinitely. Self-sustaining interventions, such as the establishment of gully control structures and the revegetation of surrounding land, may require some maintenance after major disturbances, like floods. However, these interventions become less susceptible to disturbance over time, particularly as vegetation becomes established. Restoration infrastructure and practices can, therefore, be classified into two categories on the basis of the amount and type of maintenance required: self-sustaining or ongoing (Table 1).

\section{Disturbance resilience of interventions}

Disturbance resilience is related to the capacity of the intervention (infrastructure or works such as vegetation) to continue serving a restoration function after disturbance, such as a flood event. Some interventions have a greater capacity than others to resist disturbance and therefore involve less maintenance over the long-term. We refer to the reduced impact of disturbance on an intervention as 'intervention resilience'. Most interventions will require additional maintenance after disturbance, however, some may develop resilience as projects mature. For example, gully control structures sustain less damage from flooding once vegetation has established and stabilized erosion (Weinhold, 2007). Similarly, in the case of restoring wood to streams, maintenance is required after flood events, 
until riverbank vegetation matures. The resilience of the project increases as a natural source of woody debris returns and replaces wood removed during flood events.

By contrast, fishways, and other infrastructure such as stock exclusion fencing on riverbanks (Department of Environment, Land, Water and Planning 2015), are likely to need maintenance after flooding regardless of the length of time the structure has been in operation. Interventions that must be maintained in perpetuity tend to have a low capacity to develop resilience to disturbances such as flooding and drought. We cannot examine resilience further here, however, many restoration projects can be vulnerable to flood damage, and the need for additional maintenance after flooding should be factored into management planning.

\section{Causes and symptoms}

In addition to resilience, the recovery trajectory of a degraded environmental asset following an intervention is also determined by whether interventions address causes or symptoms of degradation. The notion of symptoms refers to environmental degradation that results from the disruption of natural processes (Beechie et al., 2010). For example, river impoundment disrupts natural processes and results in degradation which could include the reversed seasonality of flows, and the declining conditions of wetland vegetation (Dyer, 2002). There are numerous options for restoring the hydrological regime to wetlands, ranging from complete reconnection of the wetland to an unregulated system, through to delivering artificial environmental flows. Environmental flows constitute,

" a suite of flow discharges of certain magnitude, timing, frequency and duration. These flows ensure a flow regime capable of sustaining a complex set of aquatic habitats and ecosystem processes" (Smakhtin \& Anputhas 2006, p.1).

The delivery of environmental flows to a wetland via irrigation channels, such as the case of Gunbower Forest in Victoria, Australia (Cooling et al. 2001), can be used to address these symptoms, but this solution does not address the underlying disruption to biophysical processes. By comparison, Beechie et al. (2010) suggest that, "Restoration actions that target the root causes of degradation are designed to correct human alterations to those driving processes" (p.213). In the case of river impoundment, an intervention that addresses the cause of degradation might involve dam removal.

Self-sustaining interventions tend to address the causes of degradation and restore natural processes. By comparison, ongoing interventions tend to address symptoms by simulating natural processes, often with solutions that involve infrastructure. In the case of wetland restoration, cause-focused intervention might involve reinstating natural flow regimes at the landscape scale by removing impoundments and ceasing extraction. By contrast, a symptom-focused intervention involves releasing environmental flows that simulate natural regimes and promote growth in the wetland.

Despite the obvious benefits of addressing the causes of degradation, many restoration projects are constrained by social, political, and economic factors that favour symptom-focused solutions (Darby \& Thorne, 1995; Davidson, 1981). This is an important distinction for two reasons. Firstly, solutions that involve infrastructure usually require ongoing maintenance to produce ecological outcomes, while solutions that reinstate natural processes can become self-sustaining. Environmental flows must be delivered to a degraded wetland for as long as the river system is regulated. Secondly, interventions that reinstate processes, such as overbank flooding, are usually more likely to produce lasting ecological outcomes in the long-term than interventions that imitate the outcomes of natural 
processes, such as reconnecting river channels with floodplains using releases from dams (Beechie $e t$ al., 2010).

The remainder of this paper is divided as follows. Firstly, we review the river restoration literature generally and demonstrate that while some interventions require regular maintenance indefinitely to achieve restoration outcomes, others are likely to require less maintenance over time, and, if managed well, can reach a point where recovery is self-perpetuating. In cases that require persistent maintenance, such as fishways, degradation will continue if the structure is not maintained. As escribed above, restoration infrastructure and practices can be divided into two categories: selfsustaining and ongoing (Table 1). Secondly, we examine the cost of river restoration projects and suggest that management arrangements for project implementation should be chosen that ensure interventions are maintained for long enough to produce the desired outcomes. Finally, we present three detailed case-studies of instream river restoration projects in Australia that bring together the elements of this paper. The case studies demonstrate how classifying interventions on the basis of maintenance can be important for making decisions about how projects should be managed.

\section{Examples of self-sustaining and ongoing river restoration interventions}

\section{Self-sustaining interventions}

Common self-sustaining interventions include practices, such as the revegetation of gullying land for morphological restoration, and infrastructure such as gully control structures. The time required for self-sustaining interventions to achieve a state where no further maintenance, or minimal maintenance is required, varies from years to centuries. To determine this timeframe the path a degraded asset is expected to take towards an improved ecological condition must first be known (Simenstad et al., 2006). The trajectory depends on how quickly the biophysical processes involved in restoration respond to the intervention. The nature of maintenance also varies. In some instances, such as sediment extraction, maintenance involves the same activities as the initial project, although the amount of maintenance required decreases. In other instances, such as dam removal, the initial activities (removing the infrastructure) and maintenance (managing downstream reaches) are different.

Some activities can become self-sustaining relatively quickly, while others might require some level of maintenance for decades to eventually reach a self-sustaining state. For example, gully control structures combined with revegetation can become self-sustaining within a decade (Hansen \& Law, 2008; Weinhold, 2007). Revegetation addresses the cause of gullying by reducing the impact of surface flows. By contrast, sediment extraction for the management of sand slugs can require decades to achieve outcomes. For example, Rutherfurd (2001) outlines a management strategy for sediment extraction to rehabilitate the Glenelg River, Australia. The recovery trajectory can be determined from the sediment transport rate, the composition of the riverbed, and the amount of stored sediment in the channel and floodplain (Rutherfurd, 2001; Bartley \& Rutherfurd, 2005; Erskine, 1994).

Depending on the regularity of extraction, environmental outcomes can be achieved in 40 to 100 years (Rutherfurd, 2001), after which time maintenance is no longer required. By contrast, it might take over a century to establish self-sustaining wood loads in rivers from a revegetated riverbank, as demonstrated in the detailed case-study below.

In practice, almost all interventions will require some form of future management, however minimal. Nonetheless, the idea that some interventions can achieve relative self-sufficiency compared to others 
which must be maintained to a high level indefinitely, has implications for how projects are managed and funded in the long-term. River managers need to ensure that funding and responsibility persist long enough for the type of project.

\section{Ongoing interventions}

Ongoing interventions involve infrastructure and practices that must be maintained in perpetuity to achieve environmental outcomes. Examples are: fishways for instream restoration, riverbank fencing for stock exclusion (Brooks \& Lake, 2007), the infrastructure and practices required to deliver environmental flows, , and actively excluding cattle from the river frontage. In all cases, if the intervention ceases, the trajectory of recovery can reverse and degradation will reoccur.

The cost of maintaining ongoing interventions, and the consequences of maintenance failure, varies between projects. Ongoing interventions that involve both high initial and high maintenance costs tend to be large-scale projects, such as the delivery of environmental flows to a large floodplain forest. For example, infrastructure, known as flow regulators, are used to divert water through the levee to the Gunbower Forest floodplain along the Murray River in SE Australia. The original flow regulator was constructed in the 1970s, was decommissioned due to lack of maintenance in the early 2000s (Cooling \& SKM, 2012) and was refurbished at a cost of \$US60 million (AWMAa, 2016). If the delivery of environmental flows cease, either due to the failure of the flow regulator, or the lack of water, the condition of the wetland will inevitably decline.

Interventions that involve high initial costs and moderate maintenance costs include large fishways. Below we describe the case of a fishway at Dights Falls in Victoria, Australia, which was refurbished at a cost of \$US1.2 million (AWMAb, 2016), and annual maintenance is upwards of \$US37, 500 (SMEC, 2010). If the fishway is not maintained, fish populations will again decline. By comparison, riparian fencing is less expensive to construct and maintain. One kilometre of stock exclusion fencing costs between \$US7, 500 and US\$22, 500, depending on materials (Alluvium, 2016), and maintenance is estimated to cost between $5 \%$ and $8 \%$ of the initial project annually (Meyer \& Olsen, 2005). Stock exclusion projects in Victoria are typically funded by government authorities, while landholders are responsible for maintenance indefinitely (DSE 2011). If landholders fail to maintain fences, or resume active grazing of the riverbank, the condition of the riverbank area will again decline. The examples of fishways and stock exclusion are described in the case-studies below in more detail.

\section{The cost of river restoration interventions}

In addition to the distinction between 'self-sustaining' and 'ongoing' river restoration interventions, the above examples suggest that interventions vary in terms of cost. Table 1 presents a summary of the activities involved in common restoration projects, and distinguishes between those activities involved for the initial implementation of projects, and those activities involved in maintenance. In that table, projects are classified according to how expensive they are to establish (initial cost) and the cost to maintain.

Table 1 here

Figure 1 demonstrates that common projects fall into four cost types, as represented by the quadrats. Projects in quadrat A are high-cost for both implementation and maintenance. Projects in quadrat B involve high initial costs, and low maintenance costs. Projects in quadrat $\mathrm{C}$ would involve low initial 
costs and high maintenance costs, however few, if any, projects fall into this category. Projects in quadrat $\mathrm{D}$ are low-cost for both implementation and maintenance.

-Figure 1 here

The type of intervention, and the cost of maintenance, should also inform how projects are managed. Ongoing interventions, particularly those that involve high maintenance costs, are more likely to succeed over the long-term if they are managed through robust arrangements. In the following section we discuss the types of management arrangements that are most appropriate for ensuring projects are maintained effectively, based on the cost of initial implementation, and the cost of maintenance.

\section{Arrangements to ensure maintenance}

Maintenance arrangements are often not designed for the length of time a structure or practice must be maintained to produce ecological outcomes. A range of maintenance arrangements are available, including legal regulation, voluntary instruments, and market based instruments (MBIs) (Gunningham $\&$ Young, 1997). The implementation of most river restoration interventions is funded by government departments, while maintenance is often the responsibility of the agencies, organizations, or individuals that benefit from the project. An in depth analysis of the specific management arrangements that are most suitable for individual restoration projects goes beyond the scope of this paper. However, we can make two observations about how projects should be managed.

Our first observation is that management arrangements often lack essential components to ensure maintenance is conducted. These components relate to the nature of regulations, contracts, or agreements established between the agencies that establish projects, and those that are responsible for maintaining the project. Successful management arrangements (and therefore in this case maintenance) require the following components: adequate funding, transparency between tiers of governance (Watson \& Emery, 2004), perceived legitimacy, and non-compliance penalties (Shimshack \& Ward, 2005). Importantly, government agencies should oversee and enforce compliance (Hartig \& Drechsler, 2008). For example, in the case of environmental flows in Victoria, both federal and state authorities were established under the Commonwealth Water Act (Australia) 2007 to govern and monitor these costly projects. Many river restoration projects lack some, or all, of these components. For example, despite the fact that fishway maintenance is mandated under statutory obligations, many have fallen into disrepair (O'Brien et al., 2010).

There is less incentive for authorities to maintain river restoration infrastructure, compared to other types of public-good infrastructure, such as roads. For example, in Victoria, government authorities are responsible for maintaining both local roads and fishways. For local roads, funding is secured by local government through public ratings under the Local Government Act 1989 (Municipal Association of Victoria, 2017). While roads are maintained to a high standard, most fishways in the state have not been maintained to operational standards (O'Brien et al., 2010). Fishways are managed by water authorities, and funding is available for maintenance. Maintenance should be conducted following a routine schedule, however, these projects suffer from a lack of responsibility, adequately trained staff, and, most importantly, the absence of oversight from an independent authority (O'Brien et al., 2010). The neglect of environmental infrastructure like fishways is a problem related to visibility and value. Citizens use roads, and understand the importance of maintenance, and will complaint to city councils if roads require repair (Victoria State Government, 2016). By comparison, environmental infrastructure, such as fishways, are often isolated, and the local community will not know if they are functioning or not. There are also few, if any, repercussions for authorities if this 
infrastructure is not maintained. Without accountability, even the best planned management arrangements cannot ensure that river restoration projects are maintained effectively.

Our second observation is that projects that require ongoing maintenance should be managed through robust arrangements that secure reliable funding streams, and either involve effective legal regulation, or offer high benefits to those individuals or agencies that are responsible for maintenance. For example, interventions like environmental flows and fishways should be managed through agencies with dedicated funding streams for maintenance, and the eventual replacement of infrastructure. These projects should be overseen by independent authorities, such as the United States Environmental Protection Agency or similar federal authorities. Less robust arrangements, such as voluntary agreements, are more suitable for projects that require decreasing maintenance and are likely to achieve a self-sustaining endpoint. However, after entering voluntarily, some agreements can become legally binding and therefore may also be appropriate for ongoing projects that involve persistent maintenance, if they meet the following requirements: high benefits for participants, compliance monitoring, non-compliance sanctions (Danne, 2003), and the threat of compulsory regulation in the case of non-compliance (Colby \& Pearson d'Estrée, 2000).

Many river restoration projects involve negotiation with landholders on a voluntary basis. For example, Bernhardt et al. (2007) found that of 37,000 river restoration projects across the U.S.A, half involved significant consultation with farming communities. Landholder consultation is often to gain consent for projects that are likely to interrupt agricultural activities, such as re-meandering projects in Europe (Vivash et al., 1998) and floodplain restoration in the United Kingdom (Adams et al., 2005). In reality, voluntary instruments rarely succeed in maintaining restoration interventions over years or decades (Danne, 2003; Race \& Curtis, 2013). For example, in Australia, landholders struggled to maintain soil conservation projects funded through voluntary arrangements (Byron \& Curtis, 2002). These projects were rarely monitored or overseen by funding authorities. Therefore, in the absence of oversight, including monitoring and enforcement, voluntary arrangements are unlikely to lead to maintenance of interventions.

Below we present three case-studies of specific types of restoration activities from south-eastern Australia (riverbank stock exclusion fencing, fish passage, and restoring instream wood) in order to explore the distinction between ongoing and self-sustaining interventions in more detail. These examples also demonstrate that the cost of projects should guide decisions about how projects are managed. We distinguish between activities and infrastructure required for the initial implementation of these interventions, and the activities required over the long-term for maintenance. We also consider recovery trajectories and maintenance trajectories. A recovery trajectory is the length of time required for an intervention to achieve environmental outcomes, and includes whether degradation will reoccur if the intervention is neglected or discontinued. The underlying biophysical processes of recovery determine the time required for a degraded asset to recover (Beechie et al., 2010). By contrast, the maintenance trajectory is the length of time restoration infrastructure and practices must be maintained to produce the target physical and ecological outcomes. It is difficult to accurately predict the recovery trajectory of a degraded asset. However, practitioners of river management are often required to make predictions of this nature, for the purpose of policy, and funding. Therefore the following is also an exercise in using available data to predict ecological recovery after intervention, for the purpose of making decisions about how maintenance of these projects could be managed.

\section{Case-studies of river restoration interventions in South-Eastern Australia}


In the following we present three case-studies of specific types of restoration activities from southeastern Australia (riverbank stock exclusion fencing, fish passage, and restoring instream wood) in order to explore the distinction between ongoing and self-sustaining interventions in more detail. Most stream restoration in Australia takes place in the humid and populated south east corner of the continent, where streams are most similar to streams in Europe and North America. Nevertheless, Rutherfurd and Gippel (2001) suggest that SE Australian streams differ from northern hemisphere counterparts in generally having higher interannual flow variability, lower sediment loads, low slopes, and anabranching panforms Looking specifically at the case studies discussed here, , in SE Australia, fishways need to pass fish with much weaker swimming ability than salmonids (Mallen-Cooper and Brand, 2007), bank erosion rates tend to be lower, and in terms of fence maintenance, peak floods tend to be much larger than average floods (McMahon et al. 1987). Nevertheless, the character, scale and management arrangements of stream restoration projects in SE Australia are very similar, to projects from the northern hemisphere.

Figure 2 here

\section{Riverbank stock exclusion fencing}

Projects to exclude stock from riverbanks are the most common river restoration projects in Australia (Brooks \& Lake 2007), North America (Kondolf et al. 2007; Wilkes et al. 2013), and South Africa (Ruwanza et al. 2013). These projects typically involve constructing fencing along the stream bank to prevent stock access. A principle purpose of stock exclusion from waterways is to protect and improve water quality (Wilcock et al. 2013). The fundamental principle is straightforward; if stock are not excluded, then water quality will rapidly decline as stock access the riverbank once more (see Figure 3).

In Victoria, 5,000km of fencing for excluding stock from riverbanks was constructed between 2006 and 2009 (Victoria State Government 2009). The estimated construction cost of $1 \mathrm{~km}$ of fencing is between \$US7, 500 and US\$22, 500, depending on the type of fencing (Alluvium 2016; Meyer \& Olsen 2005). Routine fence maintenance involves repairing posts, refastening wires, keeping wires stretched, and clearing debris from the fence line (UGC 2012) (Figure 3), at a cost of between $5 \%$ and $8 \%$ of the initial project cost (Meyer \& Olsen 2005). Fence posts and wires may last from 5 to 30 years before replacement is necessary, depending on flooding, and humidity which causes rusting (Buschermohle et al. 2016). Considering all of these factors, without maintenance, a riparian fence could stop being an effective barrier for stock after a single flood event.

Figure 3 here

Fencing addresses a symptom of degradation; grazing stock along rivers. As fencing will need to be maintained in perpetuity, we classify these projects as ongoing interventions. Fences require routine, disaster, and lifecycle maintenance. Both the initial and maintenance costs are comparatively low, therefore the project is represented in quadrant $\mathrm{D}$ of Figure 1. To ensure that these interventions are maintained indefinitely, we suggest that fencing projects should be managed through robust arrangements. Given the relatively small cost, voluntary instruments may be appropriate, if landholders perceive high benefits. This approach would require effective monitoring, and enforcement of non-compliance. In practice, stock exclusion projects are often funded through voluntary agreements between government departments and individual landholders (DSE 2011). Oneoff grants subsidize the cost of the fence, however, "financial incentives for the works component are contingent upon commitment by the landholder to long term management." (DSE 2011, p.8). 
The cost of maintenance can be prohibitive and can result in project failure. For example, project maintenance may be compromised if farmers are unwilling to continue excluding stock from the fenced frontage during times of drought and low feed availability (Moore \& Boldero, In Preparation). If voluntary approaches are unsuccessful, governments should ideally adopt more robust arrangements, such as legal regulation.

\section{Instream fish habitat structures}

Instream habitat structures for fish, including fish ladders (called fishways in Australia), are an example of a restoration activity that requires strong management arrangements to ensure that they are maintained indefinitely. The construction of artificial fish habitat began in the $19^{\text {th }}$ Century (Thompson \& Stull, 2002), and the problem of lack of maintenance has been widely recognized since the 1930s (Thompson, 2005). Without maintenance, particularly after flood events, instream structures are typically destroyed, eroded, or filled with sediment. For example, of 161 instream habitat enhancement structures in North America reviewed by Frissell and Nawa (1992), 18\% had failed and 60\% were damaged and ineffective. Thompson's (2005) maintenance conclusion is simple: all instream habitat structures, including fishways, need to be inspected and maintained after every bankfull flow, indefinitely.

Fishways are a globally important example of a fish habitat restoration structure (Kemp, 2016; Shi et al., 2015). O'Brien et al. (2010) found in Victoria, that only 7\% of 167 fishways were known to be operating effectively, $25 \%$ were in disrepair, and $47 \%$ could not be assessed because of lack of data. Maintenance failure occurred because responsibility for maintenance was either unknown, or poorly communicated. O' Brien et al. (2010) found that formal ownership was unclear for $39 \%$ of structures.

An example of fishway performance is the Dights Falls fishway on the Yarra River in Melbourne, Victoria (located at Point A on Figure 2). The first fishway at the site was constructed in 1994, but was decommissioned less than a decade later due to poor performance (Borg et al., 2014). In 2012 a new vertical slot fishway (Figure 4) was completed at Dights Falls at a cost of \$US1.7 million (AWMAb, 2016). This type of fishway involves a series of pools where the fish can rest, separated by vertical slots with higher velocities. Annual maintenance, including de-watering of the infrastructure to test functionality, and monthly removal of debris (O'Connor et al., 2015), is estimated to cost more than \$US37, 500 (SMEC, 2010). Additional inspections are also required after floods to remove debris that can jam the entrance or the slots (O'Connor et al., 2015).

-Figure 4 here

The purpose of the fishway is to restore populations of ecologically significant threatened native fishto the upstream reaches. Monitoring of the effectiveness of the fishway focused on the Common Galaxias (Galaxias maculatus) because this species was excluded by the former fishway, and it would be expected to rapidly colonise the tributaries if the fish passed the new fishway (Amstaetter et al. 2014). The fish scientists monitoring the project predicted that it would take five years for the population of Common Galaxias to recover, that is, for the fish to pass through the fishway and spread throughout the tributary network to pre-barrier densities (Amstaetter et al. 2014).

Abundant Common Galaxias were observed moving through the fishway after construction (Borg et al. 2014) and Amstaetter et al. (2014) describes the results of the monitoring program. Comparison of catch-per-unit-effort for electrofishing of Common Galaxias in the pre-treatment year (2012) and four 
years later (2015) showed an increase of 2.5 times for the reference sites (below the fishway) compared with 3.0 to 9.3 times (mean of 6.1) higher for the tributaries upstream of Dights Falls. The size distribution of the great majority of captured fish suggested that they must have passed through the fishway. Thus, for this abundant species, at least, the fishway was allowing rapid recovery of the population above the barrier. This study does not, of course, tell us how long it would take for the population to decline again if the fishway ceased to function, but for this short-lived species, it would likely decline rapidly. Discussions with Melbourne Water staff suggest that a single log jammed in one of the vertical slots can compromise this large and expensive fishway. Also, the monitoring program at this fishway demonstrates that the Common Galaxias will only migrate through the fishway at flows between 500 and 1,000 ML/day (Figure 5). If the fishway is blocked when these flows are occurring, the upstream population will again rapidly decline. Thus, this fishway must be inspected every month to ensure that it continues to perform.

-Figure 5

Fishways address a symptom of degradation rather than a cause; they are required to function for as long as there are barriers across rivers, and therefore must be maintained indefinitely. Therefore, we classify fishways as being 'ongoing' restoration projects. Fishways involve high initial costs and low maintenance costs for routine and disaster maintenance, particularly after flooding (section B of Figure 1), as well as lifecycle maintenance; because the infrastructure will also require funding when it is eventually replaced. Therefore, we suggest that robust legal arrangements are required to ensure that maintenance occurs, and to ensure funding for eventual replacement. In Victoria, many fishways fall under the jurisdiction of water authorities, such as Melbourne Water, who are legally obliged to conduct maintenance. However, the strength and effectiveness of legal instruments rests on how well they are implemented (Shimshack \& Ward, 2005). The Victorian experience with fishways demonstrates that having clear administrative responsibilities is just as important as having clear engineering systems in place.

\section{Restoring large wood in streams}

In contrast to fences and fishways, projects to restore large wood loads in streams eventually become self-sustaining as revegetated riverbanks progressively deliver wood to streams. Large wood is essential to the biological condition of rivers (Shields et al., 2003, 2006), including creating fish habitat and restoring riverbed morphology (Erskine \& Webb, 2003). The amount of large wood in rivers (known as the wood load) has declined in many rivers because logs have been directly removed (known as desnagging) to improve navigation and flood conveyance (Figure 6) (Erskine \& Webb, 2003). Wood loads have also declined because the numbers of trees on riverbanks have been depleted, reducing the source of the wood (Benda \& Sias, 2003). Projects to reestablish instream wood loads in North America (Shields et al., 2003, 2006), Australia (Bowman et al. 2014), and Central Europe (Kail \& Hering, 2005), involve the placement of logs and log-jams in channels, (known as resnagging), as well as riverbank revegetation. If resnagging is coordinated with riverbank revegetation, over time, mature tree stands will produce a passive form of restoration. Eventually this will remove the need for artificially placed wood.

Figure 6 here-

Here we consider the recovery trajectory and maintenance trajectory, for the River Murray resnagging project in SE Australia (called here the RMS Project), with the cost and trajectory shown in Figure 7. The RMS Project focused on the $200 \mathrm{~km}$ reach of the River Murray between the Hume Dam and Yarrawonga on the border of Victoria and New South Wales (Point B on Figure 2). Approximately 
24,500 snags were removed from this reach between 1976 and 1987 (DE\&E, 2014). Between 2005 and 2007, 4,500 river red gum (Eucalyptus camaldulensis) snags were restored to the reach, largely to provide habitat for native fish (Bowman et al. 2014). Nicol et al. (2004) estimated that 14,600 additional logs are required to achieve the minimum target wood load for ecological restoration of approximately 19,000 logs. These additional logs can be provided by further artificial placement (at a cost of upwards of \$US7 million for the entire reach), but also by riverbank revegetation, as mature trees fall into the channel. There are currently some mature trees on the river banks in this reach. For the purpose of demonstration, here we will assume that the entire reach requires revegetation.

Revegetation with River Red Gums would cost \$US45, 000 (ARRC, 2015a). Vegetation maintenance is estimated to cost $10 \%$ of the total revegetation project annually, over ten years, to allow vegetation to stabilize (Roni et al., 2008), including the removal of weeds, watering after dry periods, and replanting of lost saplings (ARRC, 2015b). Trees planted on these sections of the bank will take between 40 years (Wheaton et al., 2012) and 100 years (Erskine \& Webb, 2003) before the vegetation has matured into a natural source of fallen logs (Lester \& Bolton, 2008).

Maintenance costs for large wood restoration typically include replenishment and realignment due to wood movement in high flows. For example, Shields et al. $(2003,2006)$ assessed 72 wood structures placed in a $2 \mathrm{~km}$ reach of Little Topashaw Creek in Mississippi. Despite efforts to anchor $80 \%$ of structures, after 16 months approximately $30 \%$ of structures were dislodged and lost during high flows. However, Koehn et al., (2004) tracked the movement of red gum logs in the Murray River after a 1 in 20 year flood. They found that only $4 \%$ of these dense trees moved, and then only a short distance. Thus, we assume an estimate of $4 \%$ wood loss after a flood event. This situation is unusual. Other wood projects require much more maintenance as placed wood is washed away. Therefore, the amount of maintenance is likely to vary depending on the hydrological regime of the region.

Over time the artificial wood in the channel will be replaced by the River Red Gum trees that have been planted, and have matured, on the river banks. Trees will be delivered into the stream by bank erosion (Figure 7). Assuming the following, we can predict the delivery of logs into the river: trees younger than 40 years will be washed out of the reach, the lateral migration rate of the Murray River is $0.1 \mathrm{~m}$ per year (Gippell \& Blackham, 2002), $20 \%$ of the length of the stream bank is actively migrating, and a planting density of around one tree every 20 metres (50 trees per kilometre of bank). Thus, in 40 years the river migrates $20 \mathrm{~m}$, and delivers about 10 trees per kilometre to the river. Given that there are about 10 artificial logs per kilometre, and a loss rate of $4 \%$ per 20 years (Koehn et al., 2004), this means that there will be a slight increase in the wood load in the river over time (Figure 7). Note that the loss of logs, and the delivery of logs will both occur during floods, leading to a pulsed delivery.

-Figure 7 here-

Following our classification framework, resnagging projects are self-sustaining interventions when they are combined with riparian revegetation, as they are likely to reach a point where maintenance is no longer necessary for recovery, and the activities involved for the initial implementation and maintenance are the same. In conjunction with riverbank revegetation, these projects address the underlying causes of degradation by establishing a natural source of instream wood. Resnagging involves a high up-front cost, and low maintenance costs (quadrant B of Figure 1). In Australia, there is little need for disaster or lifecycle maintenance as logs are unlikely to be displaced. Some minimal routine maintenance may be required to ensure revegetation is successful. Therefore, these projects may be successfully managed using voluntary arrangements, such as negotiating access to riverbanks with landholders. However, the long-term success of resnagging projects often relies on the 
commitment of landholders to revegetate riverbanks under voluntary agreements, as outlined above in relation to stock exclusion projects. In theory, large wood projects should not require maintenance after riverbank vegetation has matured. However, projects can fail in the short-term if landholders are dissatisfied with the project (Lester \& Boulton, 2008), which can result in the removal of instream wood, particularly in the aftermath of floods. This is a response to the common belief that instream wood is dangerous for both boating and floods (Chin et al., 2014). This perception represents a key threat to the success of resnagging projects (MDBA, 2011). To be successful, resnagging projects should involve landholder engagement to ensure that wood in rivers is not removed. As suggested in the case of stock exclusion above, if landholders fail to uphold their obligations to exclude stock, more robust legal arrangements may be necessary to achieve the ecological goals of riverbank revegetation.

The three case-studies presented above demonstrate that river restoration interventions vary in terms of the amount of maintenance required to achieve ecological outcomes, and in terms of cost.

Therefore some projects require more robust management arrangements than others. Resnagging projects that involve riverbank revegetation are likely to become self-sustaining because they address the underlying cause of degradation. The initial cost is high, but managed effectively little maintenance is required. These projects can be funded through one-off grants, and managed by government departments, in consultation with landholders. However, formal agreements may be necessary if revegetation involves landholders. By contrast, both stock exclusion fencing and fishways required ongoing routine maintenance, as well as disaster maintenance after flooding, and lifecycle maintenance for the eventual replacement of infrastructure. Fishways involve much greater costs than fencing and therefore require substantial funding streams. Fencing can be managed by landholders. This is not to downplay the challenge many landholders face maintaining environmental projects, particularly in times of drought and low-farm productivity. Importantly, and particularly regarding landholders and the use of voluntary instruments, to be effective all management arrangements should involve oversight from an independent authority. Without oversight, the most sophisticated infrastructure is not likely to be maintained, and so it will fail to improve the ecological condition of the river.

\section{Conclusions}

Stream restoration is moving out of its experimental phase and increasingly becoming a main-stream practice. As we move into this next phase of stream restoration, maintenance of our interventions becomes increasingly important. Practitioners need to consider arrangements for maintenance as seriously as they consider the initial design and implementation of projects. The central conclusions of this paper are as follows:

- River restoration interventions fail when they are not maintained.

- Some interventions are self-sustaining while others require ongoing maintenance, and, importantly, the trajectory of this recovery can be predicted, and planned-for.

- How well projects are maintained depends on management arrangements. Decisions about management should be informed by the recovery trajectory of degraded environmental assets, and whether interventions address symptoms or causes of degradation.

- Interventions that are more costly, and require more maintenance, particularly those that require eventual replacement, need more reliable management instruments. Ongoing 
interventions pose the greatest challenge for river restoration because they need ongoing funding and permanent arrangements for management.

- Voluntary instruments are only appropriate when implemented effectively.

- All management arrangements require oversight from an independent authority to ensure maintenance occurs.

Establishing new river restoration projects has been a central focus of the past two decades. The problem of maintenance has emerged as projects mature. Interventions should be implemented through instruments that ensure they will be maintained long enough to allow the degraded environmental asset to follow the expected recovery trajectory through to an improved condition. We have growing confidence in many of the infrastructural and practice-based solutions to degradation. The next big challenge is to establish the same faith in how our solutions are managed. We can begin by assessing how well current management arrangements maintain existing projects. The key message of this paper is not that there is one ideal way to manage an intervention for success. Rather, that some interventions require more maintenance than others, and those that require persistent maintenance to be successful should be managed accordingly.

\section{Acknowledgments}

We thank, James Grove, Ross Hardie, and Kristie Fryiers for helpful discussion. We would also like to thank Jarrod Lyon and John Koehnand from the Arthur Rylah Institute. Comments by three anonymous reviewers substantially improved the paper.

\section{References}

Adams, W. M, Perrow, M. R, Carpenter, A. (2005). Perceptions of river managers of institutional constraints on floodplain restoration in the UK. Journal of Environmental Planning and Management, 48(6): 877-889.

Alluvium (2016). Costs of achieving the water quality targets for the Great Barrier Reef by Alluvium Consulting Australia for Department of Environment and Heritage Protection, Brisbane.

Australian River Restoration Centre. 2015a. Managing and Rehabilitating Riparian Vegetation, viewed December 14 2016, http://arrc.com.au/wpcontent/uploads/1015/08/Managing\%20and\%20rehabilitating\%20piparian\%20vegetation.pd $\underline{f}$

Australian River Restoration Centre. 2015b. A Revegetation Guide for Temperate Riparian Lands, viewed December 14 2016, https://arrc.com.au/wp-content/uploads/2015/07/RevegGuide-for-Temperate-Riparian-Lands.pdf.

AWMAa. 2016. Flood Enhancement Work for the Gunbower Forest, Consulting report to Goulburn-Murray Water, viewed November 28 2016, http://www.awmawatercontrol.com.au/projects/gunbower-forest-flooding/.

AWMAb. 2016. Penstocks for Melbourne Water Fishway at Dights Falls, viewed November 28 2016, http://www.awmawatercontrol.com.au/projects/penstocks-for-melbourne-waterfishway-at-dights-falls/.

Bartley R, Rutherfurd I. 2005. Re-evaluation of the wave model as a tool for quantifying the geomorphic recovery potential of streams disturbed by sediment slugs. Geomorphology 64 : 221-242. 
Beechie T. J, Sear D. A, Olden J. D, Pess G. R, Buffington J. M, Moir H, Roni P, Pollock M. M. 2010. Process-based principles for restoring river ecosystems. Bioscience 60: 209-222.

Benda, L.E, Sias, J.C. 2003. A quantitative framework for evaluating the mass balance of instream organic debris. Forest ecology and Management, 172(1): 1-16.

Bernhardt E. S, Palmer M. A, Allan J. D, Alexander G, Barnas K, Brooks S. 2005. Synthesizing US river restoration efforts. Science 308: 636-637.

Bernhardt E. S, Sudduth E. B, Palmer M. A, Allan J. D, Meyer J. L, Alexander G, FollastadShah J, Hassett B, Jenkinson R, Lave R, Rumps J, Pagano L. 2007. Restoring rivers one reach at a time: results from a survey of U.S. river restoration practitioners. Restoration Ecology 15(3): 482-493.

Borg, D, O'Connor, J, \& Jones, M. (2014). Evaluating the effectiveness of the Dights Falls fishway in the Yarra River, Melbourne Australia, Proceedings of the 7th Australian Stream Management Conference, Townsville, Queensland.

Bowman, H, Berry, B, Crawford, T, Martin, J, Hughes, V. 2014. Refining river works techniques through one of Australia's largest river works programs, Proceedings of the 7th Australian Stream Management Conference, Townsville, Queensland.

Brooks S. S, Lake P. S. 2007. River restoration in Victoria, Australia: change is in the wind, and none too soon. Restoration Ecology 15(3): 584-591.

Byron, I, \& Curtis A. (2002). Exploring working conditions and job related burnout in Queensland Landcare coordinators and facilitators. Johnstone Centre, Charles Sturt University.

Chin, A, Laurencio, L. R, Daniels, M. D, Wohl, E, Urban, M. A, Boyer, K. L, Butt, A, Piegay, H, Gregory, K. J. (2014). The significance of perceptions and feedbacks for effectively managing wood in rivers. River Research and Applications 30(1): 98-111.

Cooling, M. P, Lloyd, L. N, Rudd, D. J, Hogan, R. P. (2002). Environmental water requirements and management options in Gunbower Forest, Victoria. Australian Journal of Water Resources 5(1): 75-88.

Cooling, M. P, SKM (2012). Environmental Water Delivery: Gunbower Forest. Prepared by Ecological Associates and SKM for Commonwealth Environmental Water, Department of Sustainability, Environment, Water, Population and Communities, Canberra.

Danne A. P. 2003. Voluntary environmental agreements in Australia. Environmental and Planning Law Journal 20: 287-318.

Darby S. E, Thorne C. R. 1995. Fluvial maintenance operations in managed alluvial rivers. Aquatic Conservation: Marine and Freshwater Ecosystems 5: 37-54.

Davidson B. R. 1981. European Farming in Australia: An economic history of Australian Farming. NSW: University of Sydney.

Dyer, F. J. 2002. Assessing the hydrological changes to flood plain wetland inundation caused by river regulation. International Association of Hydrological Sciences, 276: 245-253.

Erskine W. 1994. River response to accelerated soil erosion in the Glenelg River catchment, Victoria. Australian Journal of Soil and Water Conservation 7(2): 39-47.

Erskine W. D, Webb A. A. 2003. Desnagging to resnagging: new directions in river rehabilitation in southeastern Australia. River Research and Applications 19: 233-249.

Frissell, C. A, Nawa, R. K. 1992. Incidence and causes of physical failure of artificial habitat structures in streams of western Oregon and Washington. North American Journal of Fisheries Management, 12(1): 182-197.

Fryirs, K, Chessman, B, \& Rutherfurd, I. 2013. Progress, problems and prospects in Australian river repair. Marine and Freshwater Research, 64(7): 642-654.

Hallwood P. 2007. Contractual difficulties in environmental management: the case of wetland 
mitigation banking. Ecological Economics 63(2-3): 446-451.

Hansen W. F, Law D. L. 2008. Gully control on the Sumter National Forest in S.C.

Proceedings of the 2008 South Carolina Water Resources Conference, held October 14-15, 2008: Charleston Area Event Center.

Heede B. H. 1977. Case study of a watershed rehabilitation project: Alkali Creek, Colorado. U.S Department of Agriculture, Forest Service, Rocky Mountain Forest and Range Experiment Station, USDA Forest Service Research Paper RM-189, June 1977.

Kail, K, Hering, D. 2005. Using large wood to restore streams in Central Europe: potential use and likely effects. Landscape Ecology 20:755-772.

Koehn, J. D, Nicol, S. J, Fairbrother, P. S. 2004. Spatial arrangement and physical characteristics of structural woody habitat in a lowland river in south-eastern Australia. Aquatic Conservation: Marine and Freshwater Ecosystems 14(5): 457-464.

Koehn, J. D, Todd, C. R. 2012. Balancing conservation and recreational fishery objectives for a threatened fish species, the Murray cod, Maccullochella peelii. Fisheries Management and Ecology 19(5): 410-425.

Kondolf G. M, Anderson S, Lave R, Pagano L, Merenlender A, Bernhardt E. S. 2007. Two decades of river restoration in California: what can we learn?. Restoration Ecology 15(3): 516-523.

Lester R. E, Boulton A. J. 2008. Rehabilitating agricultural streams in Australia with wood: a review. Environmental Management 42: 310-326.

Lorenz, A. W, Feld, C. K. 2013. Upstream river morphology and riparian land use overrule local restoration effects on ecological status assessment. Hydrobiologia 704(1): 489-501.

McMahon, T. A, Finlayson, B. L, Haines, A, Srikanthan, R. 1987. Runoff variability: a global perspective. IASH-AISH 168, 3-11.

Mallen years of data tell us about past and future fish passage?. Fisheries Management and Ecology 14(5): 319-332.

Meyer, R, Olsen, T. 2005. Estimated costs for livestock fencing, viewed November 28 2016, https://www.extension.iastate.edu/agdm/livestock/html/b1-75.html.

Morandi B, Piégay H, Lamouroux N, Vaudor L. 2014. How is success or failure in river restoration projects evaluated? Feedback from French restoration projects. Journal of Environmental Management 137: 78-188.

Municipal Association of Victoria. 2017. Council Rates and Property Valuations, viewed on 5 June 2017, http://www.mav.asn.au/about-local-government/local-governmentfinance/Pages/council-rates-property-valuations.aspx.

Murray Darling Basin Authority. 2011. Fact Sheet: Snags and Resnagging, viewed on 2 December 2016, http://www.mdba.gov.au/media-pubs/publications/fact-sheet-snags-andresnagging.

Murray Darling Basin Authority. 2016. The Living Murray Program, viewed on November 17 2016, http://www.mdba.gov.au/managing-water/environmental-water/deliveringenvironmental-water/living-murray-program.

Nagle, G. 2007. Evaluating 'natural channel design' stream projects. Hydrological Processes, 21(18): 2539-2545.

Nicol, S.J, Lieschke, J.A, Lyon, J.P, Hughes, V. 2004. Restoring structural woody habitat in the River Murray. Native fish habitat rehabilitation and management in the Murray-Darling Basin. Co-operative Research Centre for Freshwater Ecology. Albury Workshop, February.

Noonan, M. J, Grant, J. W, Jackson, C. D. 2012. A quantitative assessment of fish passage efficiency. Fish and Fisheries, 13(4): 450-464. 
O’Brien T, Ryan T, Stuart I, Saddlier S. 2010. Review of fishways in Victoria 1996-2009 (Technical Report Series No. 216). Victoria: Arthur Rylah Institute for Environmental Research, Department of Sustainability and Environment.

O'Connor, J, Mallen-Cooper, M, Stuart, I. 2015. Performance, operation and maintenance guidelines for fishways and fish passage works (Technical Report Series No. 262). Victoria: Arthur Rylah Institute for Environmental Research, Department of Environment, Land, Water and Planning.

Ormerod, S.J. (2004), A golden age of river restoration science?. Aquatic Conserv: Mar. Freshwater Ecosystems, 14: 543-549.

Palmer M, Allan J. D, Meyer J, Bernhardt E. S. 2007. River restoration in the twenty-first century: data and experimental knowledge to inform future efforts. Restoration Ecology, 15(3): 472-481.

Palmer, M. A, Menninger, H. L, Bernhardt, E. 2010. River restoration, habitat heterogeneity and biodiversity: a failure of theory or practice?. Freshwater biology, 55(s1): 205-222.

Race D, Curtis A. 2013. Reflections on the effectiveness of market-based instruments to secure long-term environmental gains in southeast Australia: understanding landholders' experiences. Society and Natural Resources: An International Journal 26(9): 1050-1065.

Roni, P, Hanson, K, Beechie, T. (2008). Global review of the physical and biological effectiveness of stream habitat rehabilitation techniques. North American Journal of Fisheries Management 28(3): 856-890.

Roscoe D. W, Hinch S. G. 2010. Effectiveness monitoring of fish passage facilities: historical trends, geographical patterns and future directions. Fish and Fisheries 11: 12-33.

Rutherfurd I. 2001. Storage and movement of slugs of sand in a large catchment: developing a plan to rehabilitate the Glenelg River, SE Australia, in Applying Geomorphology to Environmental Management, D. J. Anthony, M. D. Harvey, J. B. Laronne, \& M. P. Mosley (eds). Colorado: Water Resources Publications, 309-333.

Rutherfurd, I. D, Gippel, C. 2001. Australia versus the World: do we face special opportunities and challenges in restoring Australian streams?. Water Science and Technology 43(9): 165174.

Simenstad C, Reed D, Ford M. 2006. When is restoration not? Incorporating landscape-scale processes to restore self-sustaining ecosystems in coastal wetland restoration. Ecological Engineering 26: 27-39.

Shi, X, Kynard, B, Liu, D, Qiao, Y, Chen, Q. 2015. Development of fish passage in China. Fisheries 40(4):161-169.

Shields Jr F.D, Knight S. S, Morin N, Blank J. 2003. Response of fishes and aquatic habitats to sand-bed stream restoration using large woody debris. Hydrobiologia 494:251-257.

Shields Jr F. D, Knight S. S, Stofleth J. M. 2006. Large wood addition for aquatic habitat rehabilitation in an incised sand-bed stream, Little Topashaw Creek, Mississippi. River Research and Applications 22: 803-817.

Shimshack J. P, Ward M. B. 2005. Regulator reputation, enforcement, and management. Journal of Environmental Economics and Management 50: 519-540.

Smakhtin V, Anputhas, M. 2006. An assessment of environmental flow requirements of Indian river basins, International Water Management Institute, Research Report 107, Colombo, Sri Lanka.

SMEC. 2010. Options Analysis \& Concept Design for Fish Passage for Weirs of the Northern MurrayDarling Basin, viewed December 14 2016, http://www.dpi.nsw.gov.au/_data/assets/pdf_file/0010/634672/SMEC-Fish-PassageEngineering-Report-Final-010311_opt.pdf. 
Thompson, D. M, Stull, G. N. 2002. The development and historic use of habitat structures in channel restoration in the United States: the grand experiment in fisheries management. Géographie physique et Quaternaire, 56(1): 45-60.

Thompson, D. M. 2005. The long-term stability and morphologic influence of the use of instream structures in channel restoration design. In Managing Watersheds for Human and Natural Impacts, edited by GE Moglen. Proceedings of the 2005 Watershed Management Conference (pp. 1-9).

Tompkins M. R, Kondolf, G. M. 2007. Systematic postproject appraisals to maximize lessons learned from river restoration projects: case study of compound channel restoration projects in northern California. Restoration Ecology 15(3): 524-537.

Victorian State Government. 2009. Securing our rivers for future generations: Victorian River Health Program report card 2006-2009, viewed May 5 2017, http://www.egcma.com.au/file/file/RiverHealthProgramReportCard_Intro.pdf.

Victoria State Government. 2016. Report a road issue, viewed May 5 2017, https://www.vicroads.vic.gov.au/traffic-and-road-use/report-a-road-issue.

Vivash, R, Ottosen, O, Janes, M, Sørensen, H. V. (1998). Restoration of the rivers Brede, Cole and Skerne: a joint Danish and British EU-LIFE demonstration project, II-the river restoration works and other related practical aspects. Aquatic Conservation: Marine and Freshwater Ecosystems 8(1): 197-208.

Watson M, Emery A. R. T. 2004. Environmental management and auditing systems: the reality of environmental self-regulation. Managerial Auditing Journal 19(7): 916-928.

Weinhold M. 2007. The Alkali Creek Story: 40 years of gully control, in M Furniss, C Clifton, and K Ronnenberg (eds). Advancing the fundamental sciences: proceedings of the Forest Service National Earth Sciences Conference. San Diego, CA, 18-22 October 2004, Portland.

Wheaton J, Bennett S, Bouwes N, Camp R. 2012. Asotin Creek Intensively monitored watershed: restoration plan for Charley Creek, North Fork Asotin, and South Fork Asotin Creeks. Washington: prepared for Snake River Salmon Recovery Board, Dayton.

Wild, T. C, Bernet, J. F, Westling, E. L, Lerner, D. N. (2011). Deculverting: reviewing the evidence on the 'daylighting' and restoration of culverted rivers. Water and Environment Journal 25(3): 412-421. 
Figure Key:

\begin{tabular}{|c|c|}
\hline Figure & Caption \\
\hline 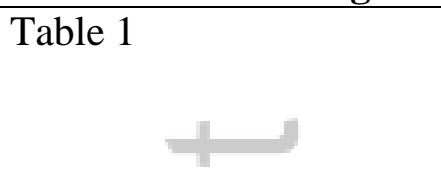 & $\begin{array}{l}\text { Table 1. Initial and maintenance activities for river } \\
\text { restoration projects, including estimated costs. (Costs are } \\
\text { roughly: Low }=\$ 10^{3}-10^{4} \text {, Medium }=\$ 10^{4}-10^{5}, \text { High }= \\
\left.\$ 10^{6}-10^{7}\right)\end{array}$ \\
\hline Figure 1 & $\begin{array}{l}\text { Figure 1. Quadrat plotting river restoration projects } \\
\text { according to initial cost and maintenance cost. } \\
\text { Note: Projects are unlikely to fall into section C of the } \\
\text { quadrat, although there may be instances that we have not } \\
\text { anticipated. }\end{array}$ \\
\hline Figure 2 & $\begin{array}{l}\text { Figure 2. Map of South Eastern Australia. Point A marks } \\
\text { the location of the Dights Falls dam and fishway in } \\
\text { Victoria. Point B marks the location of the River Murray } \\
\text { Resnagging project on the border of Victoria and New } \\
\text { South Wales. }\end{array}$ \\
\hline Figure 3 & $\begin{array}{l}\text { Figure 3. Flood damage to a riparian fence, Macquarie } \\
\text { River, Tasmania (Photo courtesy of Jimmy Collinson, } \\
\text { Greening Australia). This fence would most likely need } \\
\text { to be replaced. }\end{array}$ \\
\hline Figure 4 & $\begin{array}{l}\text { Figure 4. Aerial image of the Dights Falls Fishway on the } \\
\text { Yarra River (flow from right to left) (photo courtesy of Dr } \\
\text { Dan Borg). }\end{array}$ \\
\hline Figure 5 & $\begin{array}{l}\text { Figure 5. River f'ow compared with abun ance of } \\
\text { Common Galaxias (Galaxias maculatus) caught in the } \\
\text { vertical slot fishway (from Fig } 4 \text { in Borg et al 2014). } \\
\text { River flow compared with abundance of Common } \\
\text { Galaxias (Galaxias maculatus) caught in the vertical slot } \\
\text { fishway. The solid line shows the discharge at Dights } \\
\text { Falls. The symbols show the number of Common } \\
\text { Galaxias captured. The green triangle ( ) and purple } \\
\text { diamonds ( ) shows the number of fish captured on the } \\
\text { ramp downstream of the barrier (i.e. below the fishway). } \\
\text { The red squares ( ) show the fish captured in the } \\
\text { fishway. In general the Figure shows that the fish move } \\
\text { through the fishway when the flow is between } 500 \text { and } \\
1000 \mathrm{Ml} / \text { day. }\end{array}$ \\
\hline Figure 6 & $\begin{array}{l}\text { Figure 6. Placing a large log into the Murray River as part } \\
\text { of the Murray Darling Basin Authority's Living Murray } \\
\text { Program (photo courtesy of Jarod Lyon). }\end{array}$ \\
\hline Figure 7 & Figure 7 . The recovery trajectory of wood in rivers \\
\hline
\end{tabular}


following resnagging and the revegetation of riverbanks.

The black line represents the cumulative cost of resnagging and revegetation, including the placement of logs in streams, revegetation, and the ongoing maintenance of vegetation over 10 years. The blue line demonstrates number of logs placed in the river per kilometer via resnagging. The red line demonstrates the number of logs contributed from maturing vegetation. The dashed green line reflects the total number of logs in the river per kilometer.

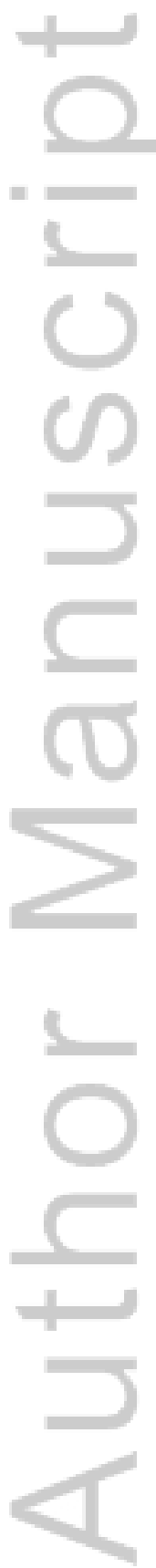

This article is protected by copyright. All rights reserved. 
Table 1. Initial and maintenance activities for river restoration projects, including estimated costs. (Costs are roughly: Low $=\$ 10^{3}-10^{4}$, Medium $=\$ 10^{4}-10^{5}, \operatorname{High}=\$ 10^{6}-10^{7}$ )

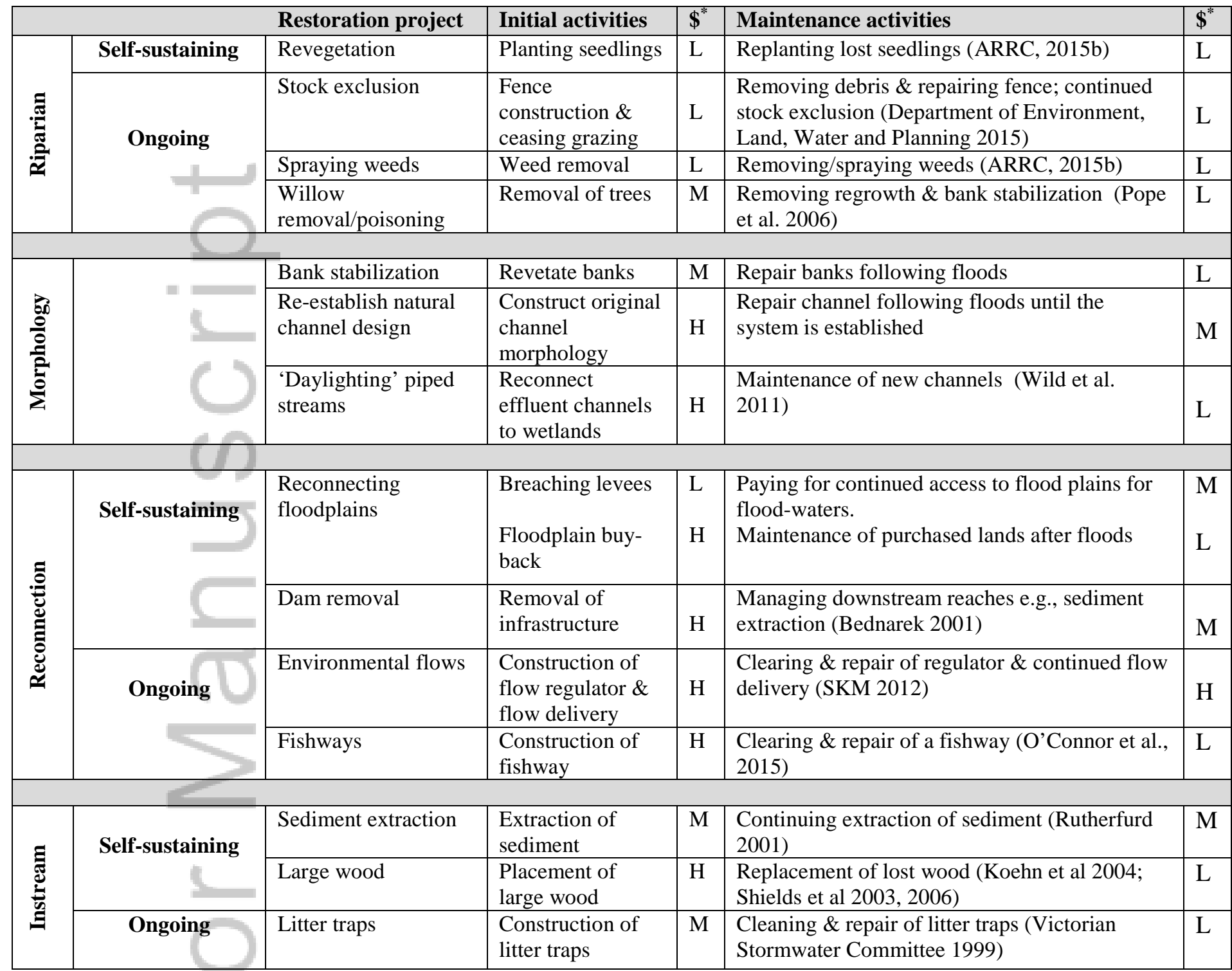




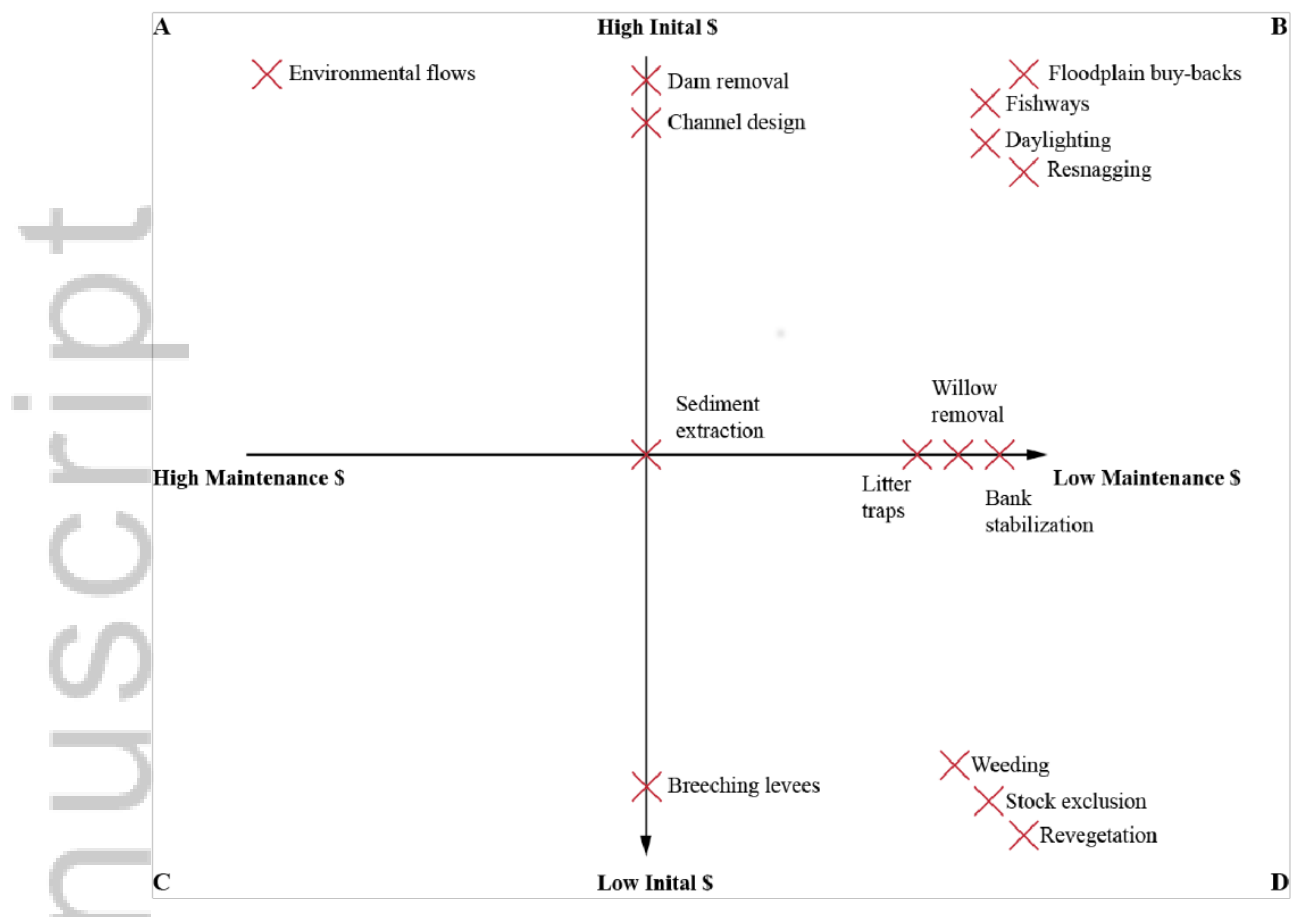

Figure 1. Quadrat plotting river restoration projects according to initial cost and maintenance cost.

Note: Projects are unlikely to fall into section $\mathrm{C}$ of the quadrat, although there may be instances that we have not anticipated.

This article is protected by copyright. All rights reserved. 


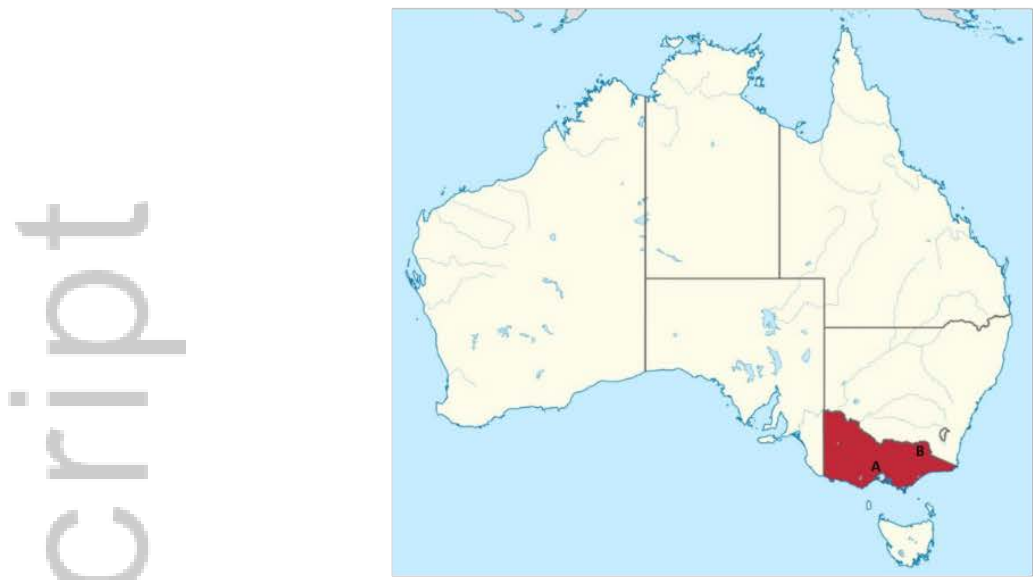

Figure 2. Map of South Eastern Australia. Point A marks the location of the Dights Falls dam and fishway in Victoria. Point B marks the location of the River Murray Resnagging project on the border of Victoria and New South Wales.
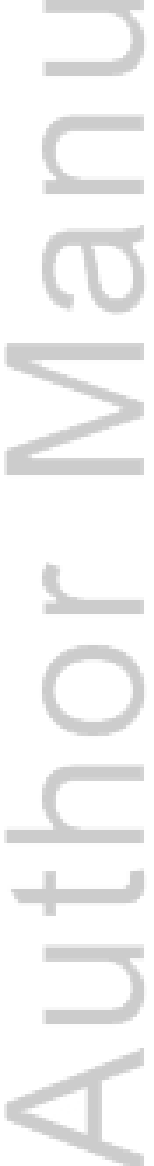

This article is protected by copyright. All rights reserved. 


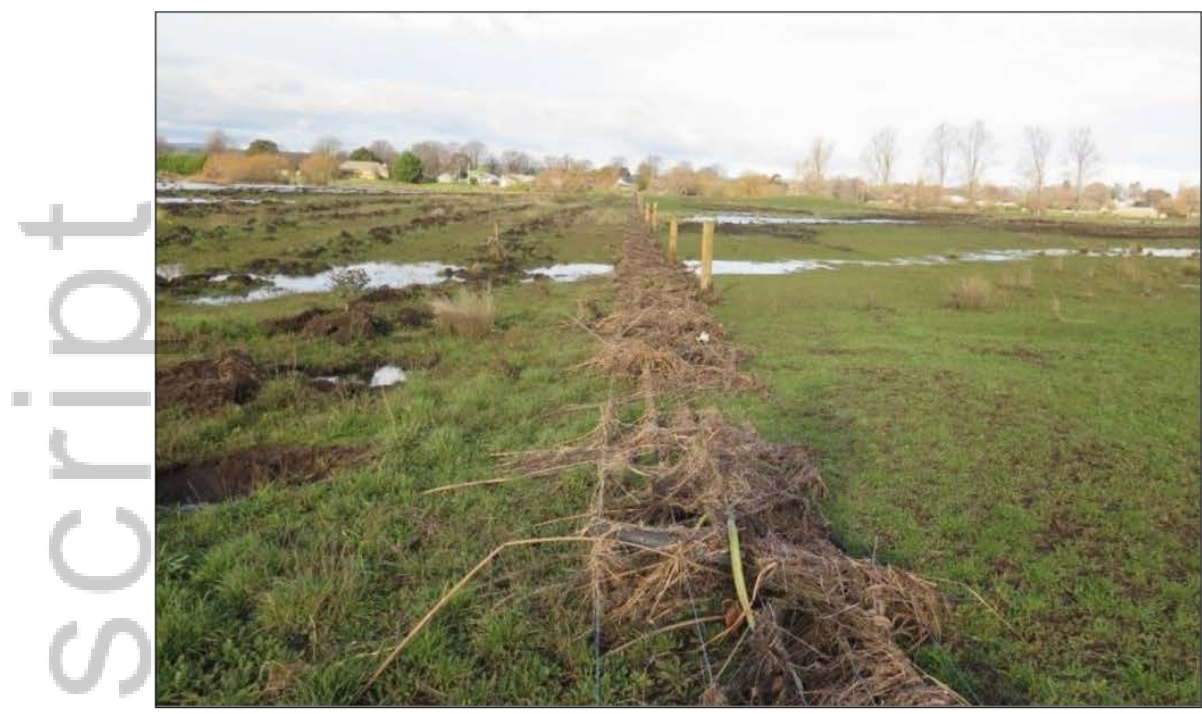

Figure 3. Flood damage to a riparian fence, Macquarie River, Tasmania (Photo courtesy of Jimmy Collinson, Greening Australia). This fence would most likely need to be replaced.

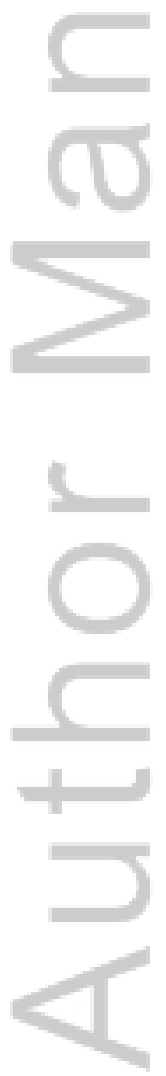

This article is protected by copyright. All rights reserved. 


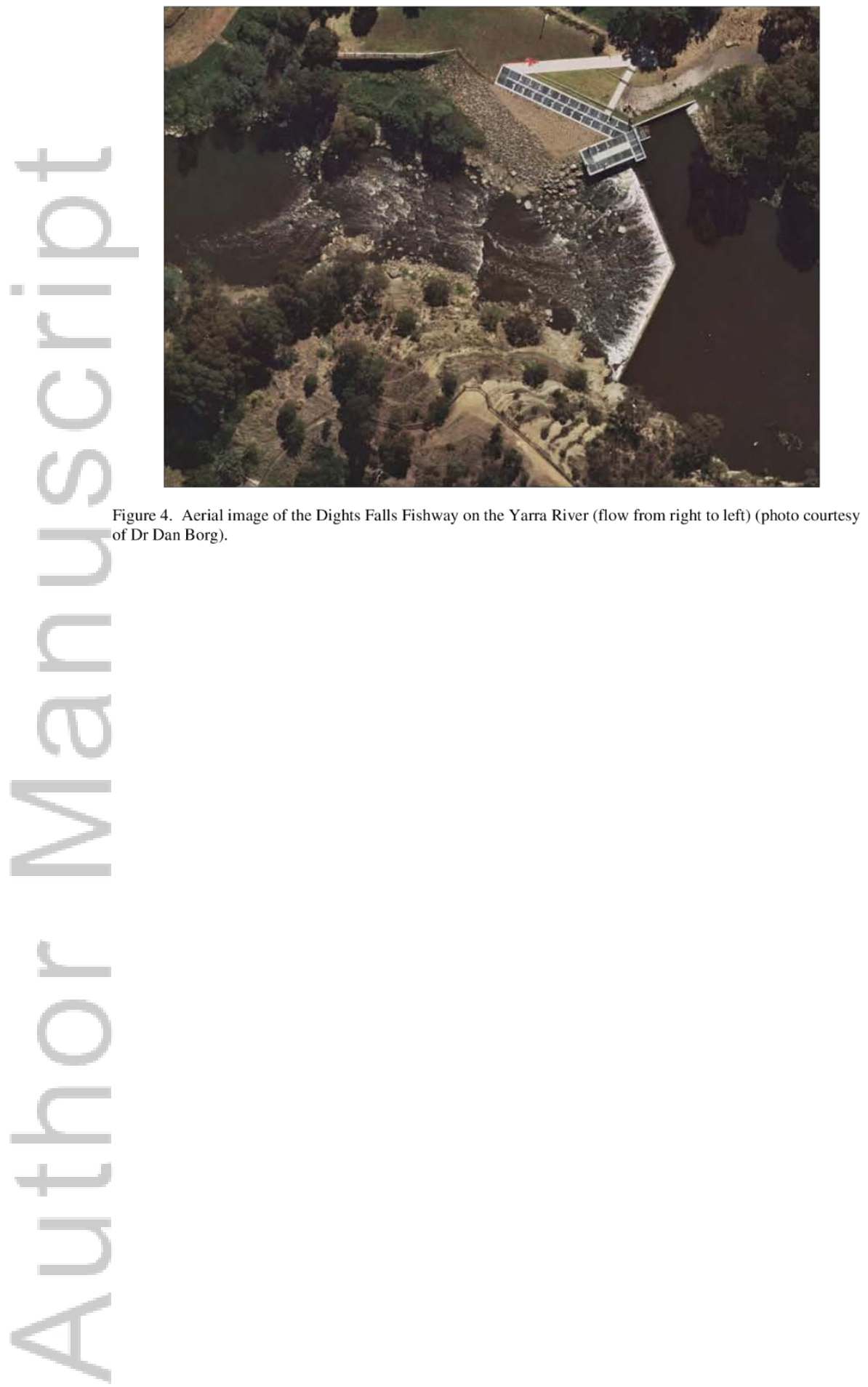

This article is protected by copyright. All rights reserved. 

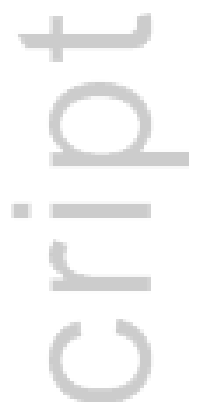

$\infty$

res
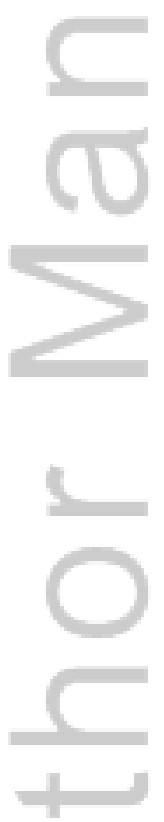

$+2$

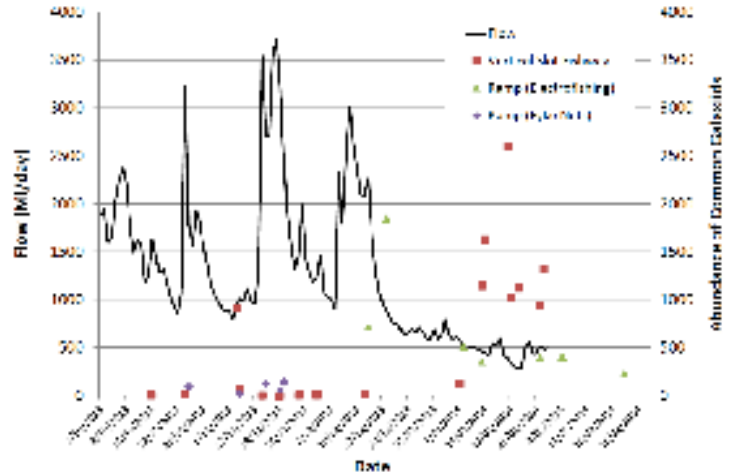

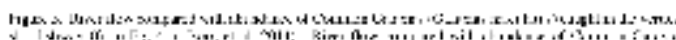

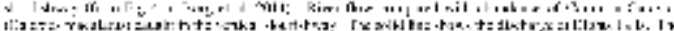

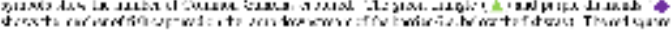

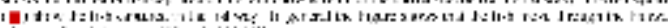




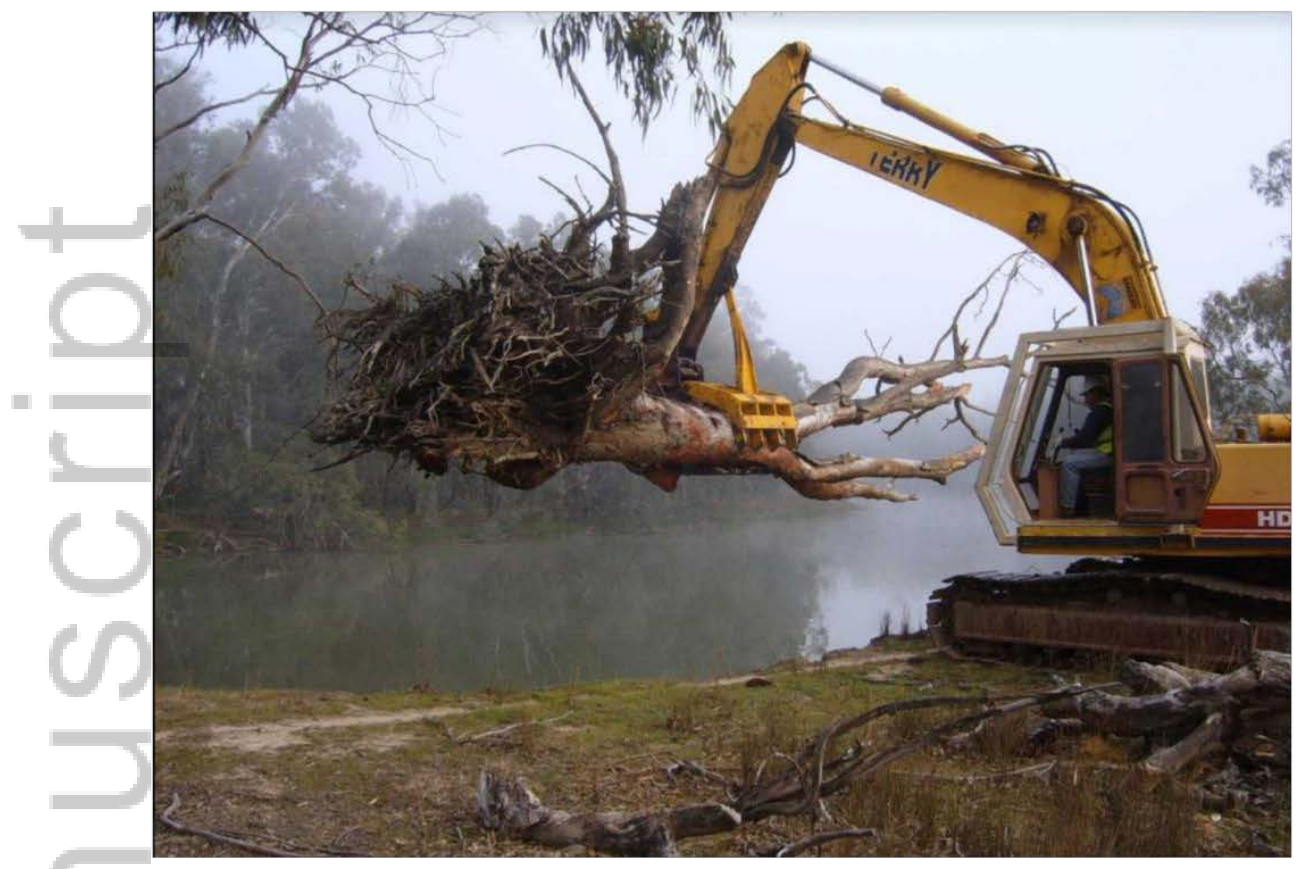

Figure 6. Placing a large log into the Murray River as part of the Murray Darling Basin Authority's Living Murray Program (photo courtesy of Jarod Lyon).
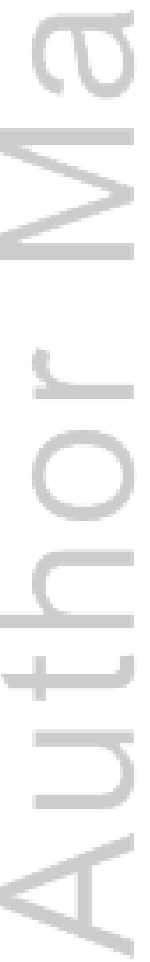

This article is protected by copyright. All rights reserved. 


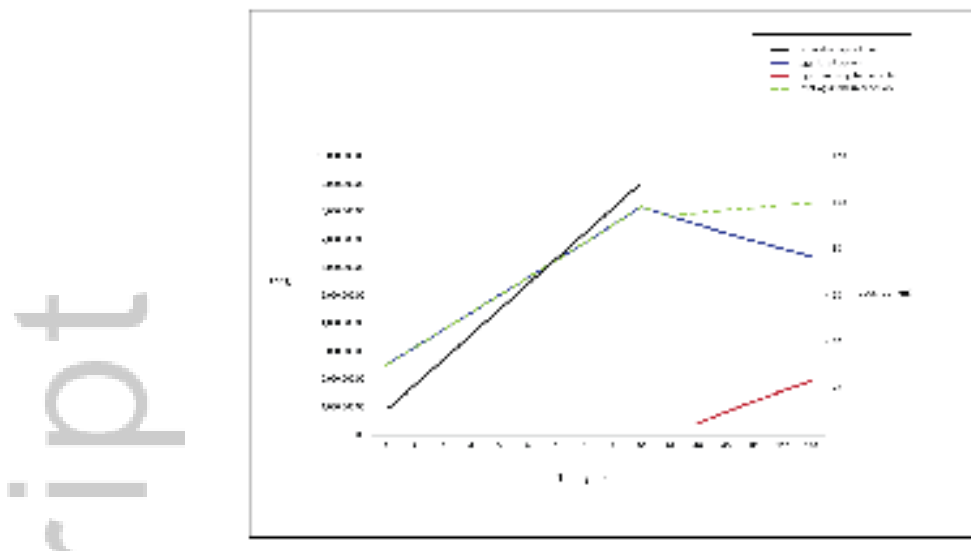

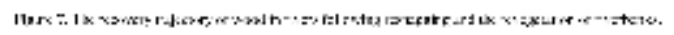

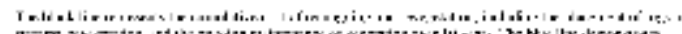

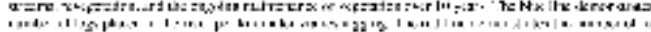

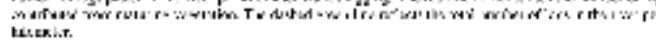

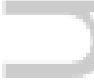

C
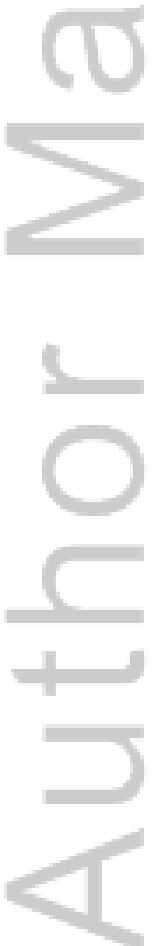

This article is protected by copyright. All rights reserved. 


\section{University Library}

\section{- M M I E R R VA A gateway to Melbourne's research publications}

Minerva Access is the Institutional Repository of The University of Melbourne

Author/s:

Moore, HE;Rutherfurd, ID

Title:

Lack of maintenance is a major challenge for stream restoration projects

Date:

2017-11-01

Citation:

Moore, H. E. \& Rutherfurd, I. D. (2017). Lack of maintenance is a major challenge for stream restoration projects. RIVER RESEARCH AND APPLICATIONS, 33 (9), pp.1387-1399. https:// doi.org/10.1002/rra.3188.

Persistent Link:

http://hdl.handle.net/11343/293423 